$\mathrm{A} \mathrm{J}_{\mathrm{sins}} \mathrm{H}$

Received : 18.04.2015

Revised : 01.05.2015

Accepted : 21.05.2015

Members of the Research Forum

Associated Authors:

${ }^{1}$ College of Horticulture and

Forestry, Central Agricultural

University, PASIGHAT

(ARUNACHAL PRADESH) INDIA
Author for correspondence :

JAHANGIR KABIR

Department of Post Harvest

Technology of Horticultural Crops,

Faculty of Horticulture

Bidhan Chandra Krishi

Viswavidyalaya, Mohanpur, NADIA

(W.B.) INDIA

Email : j_kabir@rediffmail.com
THEASIAN JOURNAL OF HORTICULTURE

Volume 10 | Issue 1 | June, 2015 | 134-138

Visit us -www.researchjournal.co.in

\title{
Efficacy of different storage conditions of okra (Abelmoschus esculentus L. Moench)
}

\section{NGANGBAM PILOO ${ }^{1}$ AND JAHANGIR KABIR}

ABSTRACT : Tender, freshly harvested fruits of cv. ARKAANAMIKA were subjected to different combination of packaging with different storage conditions viz., $\mathrm{T}_{1}=$ cool chamber, polypropylene (100 gauge) with 0 per cent perforation, $T_{2}=$ cool chamber, polypropylene (100 gauge) with 1 per cent perforation, $\mathrm{T}_{3}=\mathrm{cool}$ chamber, no packaging (in open condition), $\mathrm{T}_{4}=$ low temperature, polypropylene (100 gauge) with 0 per cent perforation, $\mathrm{T}_{5}=$ low temperature, polypropylene (100 gauge) with 1 per cent perforation, $\mathrm{T}_{6}=$ low temperature, no packaging (in open condition), $\mathrm{T}_{7}=$ room temperature, polypropylene $(100$ gauge $)$ with 0 per cent perforation, $\mathrm{T}_{8}=$ room temperature, polypropylene (100 gauge) with 1 per cent perforation, $\mathrm{T}_{9}=$ room temperature, no packaging (in open condition). The temperature during storage period at cool chamber varied from $22^{\circ} \mathrm{C}$ to $28^{\circ} \mathrm{C}$, respectively and relative humidity varied from 90 per cent to 94 per cent. Low temperature condition was maintained at $8 \pm 1^{\circ} \mathrm{C}$ and relative humidity was around 67 per cent (outside plastic) and 80 per cent (inside plastic) during the storage period. The temperature during storage at room temperature condition varied from $28^{\circ} \mathrm{C}$ to $33^{\circ} \mathrm{C}$, respectively and relative humidity varied from 60.5 to 72 per cent and 65.5 to 77 per cent. Results indicate that $\mathrm{T}_{4}$ (low temperature + polypropylene $+0 \%$ perforation) at a temperature of $8 \pm 1{ }^{0} \mathrm{C}$ and relative humidity 80 per cent was the best treatment for storage of okra. It increased the shelf-life upto 12 days by considerably reducing the PLW, blackening, yellowing, retaining sensory quality, increases marketability. It also retained the ascorbic acid and chlorophyll content better during storage. Cool chamber was suitable for storing okra for 10 days with or without polypropylene.

KEY WORDS : Cool chamber, Low temperature, Okra, Polypropylene, Storage

HOW TO CITE THIS ARTICLE : Piloo, Ngangbam and Kabir, Jahangir (2015). Efficacy of different storage conditions of okra (Abelmoschus esculentus L. Moench). Asian J. Hort., 10(1) : 134-138. 